\title{
Establishing Socialist Democracy in Vietnam in the Renovation Period
}

\author{
Dinh Van Chi \\ Faculty of Party Building, Ho Chi Minh City Cadre Academy, Ho Chi Minh City, Vietnam
}

Email address:

dinhvanchi84@gmail.com

\section{To cite this article:}

Dinh Van Chi. Establishing Socialist Democracy in Vietnam in the Renovation Period. International Journal of Philosophy.

Vol. 9, No. 3, 2021, pp. 136-142. doi: 10.11648/j.ijp.20210903.13

Received: July 5, 2021; Accepted: July 19, 2021; Published: July 23, 2021

\begin{abstract}
The purpose of this study is to learn about the establishment of socialist democracy in Vietnam during the renovation period in Vietnam. This study focuses on analyzing theoretical and practical bases; evaluating and analyzing new contents and problems posed in the perception of socialist democracy and establishing socialist democracy in Vietnam through 35 years of renovation. In this study, the author makes two hypotheses: 1/ The theories and practices of establishing socialist democracy in Vietnam during the renovation period shows that the Communist Party of Vietnam and the Vietnamese people are right; 2/ The establishment of socialist democracy in Vietnam today has achieved many great achievements. Besides these achievements, there are also problems with establishing socialist democracy in our country in the renovation period. The results of the study show that building and perfecting the socialist rule-of-law State, renovating and democratizing the organization and operation of the political system under the leadership of the Party are the conditions for exercising socialist democracy in terms of politics in Vietnam. Besides, developing a socialist-oriented market economy also creates favorable conditions for establishing socialist democracy in the economic field. In addition, it is necessary to build and develop an advanced Vietnamese culture imbued with national identity, unity in diversity, national characteristics, humanity, and science are actual conditions for exercising socialist democracy in the field of culture in Vietnam. To obtain the research objectives, the author has used scientific research methods such as analysis and synthesis, deductive and inductive, abstraction and generalization, logic, history, and comparison to come to the findings and recommendations of the study.
\end{abstract}

Keywords: Establish, Socialist Democracy, Vietnam, Renovation Period

\section{Introduction}

In the years of conducting renovation, by summarizing practice and theoretical research, the Communist Party of Vietnam gradually became more and more deeply aware of socialism and the transitional period [1]. In Vietnam, by initiating and leading the renovation process, the Communist Party of Vietnam has continued to demonstrate its intelligence, bravery, and responsibility to the important issues of the Fatherland since 1986. Establishing socialist democracy has become one of the permanent concerns in the Party's awareness and actions. Accordingly, the democratization of all areas of social life has always been affirmed by our Party as one of the basic goals, tasks, and focus of the renovation work. The Party's new thinking and awareness of socialist democracy direct the process of democratizing social life, and the practice of democratization is the foundation for testing and supplementing the awareness of socialist democracy and building socialist democracy.

Under the leadership of the Communist Party of Vietnam, in the spirit of democracy and renovation, our country has achieved great achievements of historical significance over the past 35 years. In particular, achievements in establishing and promoting socialist democracy have special significance. The power, the interests, the role of the people, and the political activeness of the people are increasingly expressed and strongly promoted. Exercising and promoting democracy becomes the content, organization, and operation of the whole political system and each member organization. Socialist democracy is both a result of innovation and a driving force for innovation. Theoretical perception of socialist democracy has made many new points, and the exercise of building socialist democracy has made critical changes. However, the above results and achievements of the 
process of awareness and exercise of socialist democracy in our country are only the first step. The process of understanding socialist democracy in many respects and establishing socialist democracy has many shortcomings, limitations, and many complicated problems over the past 35 years. Many aspects of socialist democracy and establishing socialist democracy have not been fully understood, showing dogmatism and leading to a lack of consistency in practice. These issues include establishing socialist democracy in terms of a ruling communist party, ensuring people's power, implementing social justice and equality, developing people and Vietnamese culture in the context of market economic development and international integration, building a socialist rule of law state of the people, by the people, for the people, controlling state power and, anti-recession, antibureaucracy, and anti-corruption. This is the reason why the author chooses "Establishing a socialist democracy in Vietnam in the renovation period" as the research topic.

\section{Literature Review}

\subsection{Socialist Democracy in Vietnam as a Political System, a Form of State That Ensures Power Belongs to the People}

Firstly, using the concept of the political system and clarifying the organizational and operational mechanism of the political system in our country. Since the Party Central Committee's sixth plenum (1989), our Party has used the concept of the political system instead of the concept of the dictatorship of the proletariat. Our Party has stated very clearly that innovating the organization and operation of the political system is to strengthen the leadership role of the Party, the effectiveness of the State's management, and promote the people's mastery, which increases the strength and effectiveness of the dictatorship of the proletariat and make organizations in the political system operate more dynamic and effective [2]. Socialist democracy in Vietnam is first expressed and exercised through the socialist political system including the Communist Party of Vietnam, the Socialist Republic of Vietnam under the rule of law, the Vietnam Fatherland Front, and socio-political organizations. It is operated according to the following mechanism: the Party leads, the State manages, and the people own it. This perception is the result of the creatively developed inheritance of the views of Marxism-Leninism and Ho Chi Minh Thought.

Second, using the concept of the rule-of-law state and clarifying the basic features of the socialist rule-of-law state in Vietnam. During the renovation process, our Party has identified the socialist state as the central part of the political system and socialist democracy. The concept of the rule of law was mentioned at the Second Plenum of the 7th Party Central Executive Committee (November 1991) and officially used in the Document of the Mid-term Conference of the 7th Central Committee in January 1994 [3]. Since then, in the renovation process, the theory of building a socialist rule of law state in Vietnam has been continuously supplemented and developed by our Party. After 35 years of renovation, through the documents of the Party and the State, in the theoretical perception of our Party, the Socialist ruleof-law State of Vietnam includes the following basic characteristics: First, the Socialist rule-of-law State of Vietnam is the State of the People, by the People, for the People, demonstrating the People's right to mastery. Second, the socialist rule-of-law state of Vietnam is organized and operated based on the Constitution, respecting and protecting the Constitution. Third, the rule-of-law state of Vietnam manages society by law, ensuring the supreme position of the law in social life. Fourth, the Socialist rule-of-law State of Vietnam respects and protects human rights, citizens' rights, and freedoms, maintaining the relationship between the State and citizens, the State and society. Fifth, in the socialist ruleof-law state of Vietnam, state power is unified, with assignment and coordination of control among state agencies in the exercise of legislative, executive, and judicial powers. There is a strict inspection and supervision in the exercise of state power. Sixth, the Socialist rule-of-law State of Vietnam is the state led by the Communist Party of Vietnam [4].

The above characteristics confirm that the socialist rule-oflaw state is a pillar organization of socialist democracy in Vietnam during the transition to socialism. This is the product of our Party's process of dialectical perception based on Marxist materialist methodology. This is the product of our Party's process of dialectical perception based on Marxist materialist methodology. Refusing to be more aware of the role of law and to realize that the rule of law is not a unique product of capitalism, coming to acknowledge and then officially use the concept of rule of law, the socialist rule-oflaw state step by step has identified the contents, characteristics, and requirements for building a socialist rule of law state suitable to Vietnam's economic, political, cultural and social conditions in the context of promoting industrialization, modernization, and developing a socialistoriented market economy and international integration. Great progress has been made on the path of theoretical awareness and practice of building a socialist rule of law state in Vietnam during the past 35 years.

\subsection{Dialectical Unity Between the Nature of the Working Class, the People, the Nationalism and the Humanity of Socialist Democracy in Vietnam}

During the renovation period, our Party not only correctly perceived the views of the classics but also creatively applied, supplemented, and developed these views to be suitable with the new conditions of our country. Accordingly, our Party has gained new perceptions about the content and relationship between the nature of the working class, the people, the ethnicity, and the humanity of socialist democracy. Firstly, the nature of the working class of socialist democracy in Vietnam is demonstrated in the fact that all fields from politics, ideology, economy, society, national defense, security, foreign affairs, building and exercising the law, and recruiting cadres must deeply reflect 
the thoughts and views of the working class [5]. The socialist state and socialist democracy in Vietnam take the alliance of the working class with the peasantry and the intelligentsia as the foundation, led by the Communist Party to serve the interests of the working class and the people and of the whole nation; exercising the people's mastery and dictatorship with acts that infringe upon the interests of the people and violate the national security. The Party's new and profound awareness of this content in the renovation period is reflected in many aspects.

Second, the widespread citizenship of socialist democracy in our country is demonstrated: the Socialist Republic of Vietnam is governed by the people [6]. "People are the foundation", which means all state power belongs to the people, the authority of the state apparatus belongs to the people and is entrusted to them [7]. The people are the supreme subject of the state power: the origin, nature, purpose of existence, strength of the state, originating from the people. The State is established by the people, elected by the people, supervised, and dismissed by the people. The strength of the State and socialist democracy in Vietnam is the great unity of the people, with the union of the working class, the peasantry and intelligentsia as the foundation.

Third, the profound national identity of socialist democracy in our country reflected the fact that the State and socialist democracy in Vietnam are the achievements of the long and arduous revolutionary struggle of Vietnamese people, from the People's Democratic National Revolution to the Socialist Revolution, which was led by the Communist Party of Vietnam. In the socialist democracy in Vietnam, people of all ethnic groups are equal, unite and help each other develop. During the renovation process, the Party's awareness of the national identity of socialist democracy in Vietnam is shown: First, the foundation of socialist democracy is the strength of the national unity bloc, inheriting and promoting the experience of community organization and social management of previous generations. Second, learning and referring to the world's democracy must come from the reality and life of Vietnamese society. Third, along with Marxism-Leninism, Ho Chi Minh thought is the ideological and theoretical foundation of socialist democracy in Vietnam. Fourth, there is no objective foundation for the multi-party regime in Vietnam. Socialist democracy has to be led by the Communist Party of Viet. In the renewal process, there has been an important change in the Party's awareness of the nationalism of socialist democracy in Vietnam. This is a complement to Marxism-Leninism and the development of Ho Chi Minh Thought in new conditions [8].

Fourth, the humanity of socialist democracy is also a great concern of our Party during the renovation period, both in terms of perception and practice [9]. The combination of traditional, modern, and international factors and the combination of national strength with the strength of the times have always been considered by our Party as an important lesson to emphasize the process of building socialism and establishing a socialist democracy. The new characteristics here reflected several main aspects: First,
Vietnam from a semi-feudal colonial society, skipped bourgeois democracy to advance to people's democracy and socialist democracy, so we must fight against the manifestations of formal democracy, capitalist democracy to inherit and selectively absorb the democratic values of humans, especially experience, the progressive democratic values that humans have achieved under the capitalist regime. Second, the socialist-oriented market economy and the socialist rule-of-law state to guarantee citizens' rights and human rights are a profound combination of the democratic values of humanity with the socialist democracy in Vietnam under the new situation of the country and the times. That was a crucial breakthrough in our Party's awareness of socialist democracy in the renovation period.

\subsection{Socialist Democracy in Vietnam Is the Result of the People's Revolutionary Struggle Under the Leadership of the Party}

The awareness of socialist democracy as the goal and driving force of the renovation process has become one of the new contents showing a remarkable development in the Party's thinking and theoretical awareness on socialist democracy in Vietnam [10].

First, Socialist democracy - the goal of the renovation cause and the construction of socialism in Vietnam: Setting goals is one of the critical issues of communist parties in the stage of the socialist revolution. The presence of socialist democracy in the target system of socialism over the past 35 years has shown remarkable development in the theoretical thinking of our Party.

Second, socialist democracy is the driving force of the renovation and socialist construction in Vietnam. Determining the right motivation is a fundamental task in the revolutionary path, and it is also a significant factor to ensure the successful implementation of that path. The presence of democracy in the renovation system and becoming one of the driving forces of socialism is a new point in our Party's theoretical awareness of socialism and socialist democracy.

\subsection{The Mechanisms and Principles of Organization and Operation of Socialist Democracy in Vietnam}

The decisive factor in the effectiveness of democratic mechanisms and principles is the awareness and resolution of the relationship between people and organizations, people and people, organizations and organizations, and individuals with collectives, subordinate to superior, local and central, rights and obligations, democracy and law, discipline, democracy, and centralization. Generalizing the settlement of those relations into principles, V. I. Lenin called it democratic centralism and Ho Chi Minh mainly used the concept of centralized democracy [6]. In the pre-renovation period, our Party affirmed that democratic centralism was the most common mechanism and the principle of leadership, management, and practice of socialist democracy in Vietnam. However, both in understanding and dealing with practical problems, our Party has not yet harmoniously handled the 
above-mentioned complex relationships, which has led to bureaucratic concentration and the lack of realistic vitality in people's collective mastery. Therefore, the development of theoretical awareness about the mechanism and principles of organizing and operating the socialist democracy has become one of the concerns of our Party in the renovation process. The principle of democratic centralism has been applied, developed, and institutionalized into specific principles and mechanisms with increasing legal validity and practicality.

First, regarding new awareness of the principle and mechanism of "the Party leads, the State manages, the people are masters" in the organization, operation of the political and organizational system, and the operation of the entire social life: in the renovation, our Party had to define more clearly its functions and tasks and better handle the relationship between the Party and the State and mass organizations.

Second, there is a remarkable renovation in the perception of the relationship between democracy and centralization in a socialist democracy. It reflected the following principles: the collective lead and the individual in charge; the minority submits to the majority; subordinates have to obey superiors; individuals have to conform to the organization; democracy associated with the unity of the whole people and social consensus based on taking the common goal of independence, unity, rich people, strong country, democracy, fairness, and civilization; state power is unified, with assignment, division of duties, levels of authority, coordination and mutual control, and at the same time, ensuring the direction of the Central Government.

Third, a deep awareness of the relationship between rights and obligations and responsibilities in a socialist democracy. During the renovation process, our Party has affirmed: rights go hand in hand with obligations and responsibilities. More rights, greater responsibility. Citizenship is inseparable from civic duty, and everyone must respect the rights of others. The exercise of human rights and citizens' rights must not infringe upon the national interests and the fundamental rights of others. The people not only have the rights but also the responsibilities to participate in the planning and implementation of the guidelines and policies of the Party and the laws of the State. The Party exercises its leadership over the State and society; it has a mission, responsibility to serve the people, is subject to the people's supervision, and is accountable to the people for its decisions. The State exercises the right to manage all aspects of social life by the Constitution and laws; it has the obligation and responsibility to recognize, respect, protect and guarantee human rights and citizens' rights; take care of the happiness and free development of each person.

Fourth, a deep awareness of the relationship between democratic issues and discipline. In the renovation process, socialist democracy in Vietnam, democracy has gone hand in hand with rules; democracy, dictatorship, and rules have been institutionalized and guaranteed by law. All citizens are equal before the law. Human rights and citizens' rights are recognized, respected, protected, and guaranteed according to the Constitution and laws. Establish democracy with the people and strictly punish those who sabotage the achievements of the revolution, security, order, and social safety. Establish democracy and prevent actively and resolutely fight against corruption and waste with the strength of the whole political system and the entire people; synchronously implement political, ideological, organizational, administrative, economic, and criminal solutions.

Fifth, in terms of a new awareness of the diversity and richness of forms and mechanisms for establishing socialist democracy of the political system as well as socio-political organizations and of the whole society in general: There are many forms and mechanisms of democracy, such as: questioning and answering questions of the National Assembly and People's Councils, which are reported live on radio and television; the public form of examination conclusions and discipline of party members and party organizations; diversified forms of collecting comments from the people on draft legal documents, the Constitution and documents of the Party congress; conduct face-to-face, online dialogue; carry out the supervision of the National Assembly, the People's Council; carry out social criticism of the press, the Fatherland Front and its member organizations; implement the self-governing conventions and conventions of the people; implement democratic regulations at various grassroots levels.

\subsection{A more Correct and Transparent Perception of Socialist Democracy in Vietnam}

Since 1986, our Party has had new perceptions of socialist democracy in Vietnam as social values, human values, and civilization reflecting the state and degree of human liberation in the stage of social development.

Firstly, in the renovation, our Party realizes that socialist democracy in Vietnam is a democracy that is guaranteed to be established in all areas of social life, from the economy, politics to culture and society. Democracy is fully established at all levels and branches, focusing on the grassroots level, at all types of establishments, especially in rural areas. All guidelines, policies, and laws of the Party and State, must be for the benefit of the people, with the participation of the people's opinions. Socialist democracy in Vietnam has been established by a combination of direct democracy and representative democracy, associated with social justice, national unity, and social consensus to ensure human rights and citizens' rights so that benefits can go hand in hand with obligations and responsibilities, and punish all acts that infringe upon the interests of the people and the country. Democracy needs to be associated with centralization; democracy goes hand in hand with discipline and discipline, institutionalized by law, within the framework of the law, and guaranteed by law.

Second, during the renovation period, our Party has realized that socialist democracy is the essence of our regime, both the goal and driving force of innovation and development and the cause of socialist construction in Vietnam. Socialist democracy is not only a humanistic goal, 
ideal, and aspiration but it also becomes the Constitution and laws of the State, mechanisms, policies, and principles of organization and operation of the Party, State and sociopolitical organizations, styles, methods of leadership, and social management. It has become the daily reality of each person, community, organization, economic, political, educational, cultural, and social unit at all levels. Socialist democracy is not only about voting and standing for election, but it is also about freedom of thought and expression. It is also about ensuring justice, national unity, social consensus and liberating productive forces, developing production, and promoting industrialization and modernization of our country.

Third, socialist democracy in Vietnam is established with a socialist-oriented market economy, by the socialist political system and the socialist rule-of-law state led by the Party. It is a democracy that has been established by modern mechanisms, forms, methods, and economic and political institutions suitable to Vietnamese economic, political, historical, traditional, and cultural conditions and led by a Communist Party with wisdom, bravery, and experience that always faithfully represents the interests of the working class, the working people and the whole Vietnamese nation.

Fourth, during the renovation process, our Party has had a deep awareness of the mastery right of the people. The entire Vietnamese people, including workers, farmers, intellectuals, businessmen, women, veterans, the old, people of all ethnicities, religions, and Vietnamese people living abroad are the owner of socialist democracy, the force that creates socialist democratic values in Vietnam, and the beneficiaries of those democratic values are the Party's guidelines, the State's policies, and laws not only ensure citizens' rights but also ensure human rights. They not only focus on ensuring freedom and democracy of basic sections of the people, but they also pay attention to and ensuring the democratic rights of all people with very diverse sections

\section{Results and Discussion}

\subsection{Results of Establishing Socialist Democracy in Vietnam}

Firstly, building and perfecting the socialist rule-of-law State, renovating and democratizing the organization and operation of the political system under the leadership of the Party are the conditions for exercising socialist democracy in terms of politics in Vietnam. After 35 years of renovation, the Party's theoretical awareness of political conditions and the content of political socialist democracy establishment in our country regarding the renewal and democratization of the organization and operation of the political system must adhere to certain principles and mechanisms. Renovate radically and synchronously, and comprehensively democratize the organization and operation of the socialist political system with appropriate forms and steps, harmoniously combining renovation from grassroots to central level. Be aware of and well deal with the relationship between the Party's leadership, the State's management, and the people's ownership. Recognize and harmoniously resolve the relationship between democracy and centralization; democratic centralization with democratic consultation; representative democracy with direct democracy; rights, obligations, and responsibilities; democracy, discipline, and law. Establish and perfect democratic institutions to concretize, detail, and legislate the motto "people know, people discuss, people do, people inspect". Accordingly, "it is necessary to focus on building legal documents directly related to the people's right to mastery. Institutionalize and improve the quality of direct and representative democracy. Implement human rights, basic rights and obligations of citizens according to the 2013 Constitution" [11]. Such regulations and institutions must be detailed, specific, and feasible.

The exercise of democratizing social life and the achievements of socialist democracy in all fields of the country, in which the achievements of implementing socialist democracy in the political realm show the direction and policy of the Party on building a socialist rule-of-law state. Renovating and democratizing the organization and operation of the political system are correct. Building and perfecting the socialist rule-of-law State, renovating, democratizing the organization and operation of the political system is both a political condition and a basic content in the exercise of political socialist democracy in our country. It indicates that our Party is not only loyal to Marxism-Leninism and Ho Chi Minh Thought, but it also applies, complements, and creatively develops the ideas of philosophers following the changes of our country and times.

Second, developing a socialist-oriented market economy creates favorable conditions for establishing socialist democracy in the economic field in Vietnam. After 35 years of renovation, our Party has formed a new system of theoretical views on building economic conditions and content of socialist democracy in Vietnam. It is essential to develop modern productive forces through renovating growth models and restructuring the economy and promote industrialization and modernization of the country and establish appropriate progressive production relations (both ownership, management, and distribution relations) with the development level of the productive forces by developing a socialist-oriented market economy [12]. Conditions and economic foundation are the basic mechanisms, content, method, and indispensable path for the practice of economic socialist democracy in the transition to socialism in our country. It is the application and creative development of the democratic theory of Marxism-Leninism (especially the New Economic Policy of Lenin), the democratic thought of Ho Chi Minh, and the viewpoints on the multi-sector economic development of our Party in the initial steps of building socialism in the North. It is crucial theoretical creativity with the profound practical significance of our Party in the renovation process. The achievements of the democratization of the country's social life over the past 35 years, especially the achievements in exercising socialist democracy in the economic area derived directly from the Party's theoretical 
perspectives on the development of a socialist-oriented market economy.

Third, it is necessary to build and develop an advanced Vietnamese culture imbued with national identity, unity in diversity and national characteristics, humanity, science are actual conditions for exercising socialist democracy in the field of culture in Vietnam. Looking directly at the truth, properly assessing the truth, and stating the truth of the 6th National Party Congress, in 1988, in Resolution No. 05NQ/TW of the Politburo, our Party assessed: "For many years, there has never been a time to carefully discuss and issue a resolution on culture and arts, and have not paid attention to improving cultural and artistic leadership methods to suit the new situation". Cultural leadership and management Culture and art have many simple expressions, lack of democracy [13]. Our Party has innovated thinking and developed theoretical awareness about cultural conditions and exercised socialist democracy in the cultural field in our country. Accordingly, the cultural issues and content of the exercise of socialist democracy in the cultural field in our country are to build and develop an advanced Vietnamese culture imbued with national identity, unity in diversity with characteristics of the nation, humanity, democracy, and science. This is the application and development of the idea of building a proletarian culture of Marxism-Leninism, the thought of building a new culture of Ho Chi Minh and our Party in the pre-renovation period include the spirit of nationalism, science, and mass from the Party's Outline of Vietnamese Culture (1943). In the renewal process, the issue of building culture as a condition for exercising socialist democracy is increasingly placed by our Party in close correlation with economic political and social conditions and market economy development, building a socialist rule of law state and extensive international integration. These theoretical views have not only reflected vividly the reality of innovation and democratization of the country's social life, but they also directly oriented and guided the process of socialist democratization in the field of culture in Vietnam over the past 35 years.

Fourthly, building and developing a society of solidarity, consensus, fairness, well-being, and civilization - which are conditions and contents for implementing socialist democracy in the social field in Vietnam. The point of view of Marx, Engels, Lenin, and Ho Chi Minh on solving social problems and implementing socialist democracy in the social realm is to build and develop an equal and progressive society. In the renovation period, although the social development model has not been officially defined in general, the basic contents of that model have been confirmed [14]. Solidarity, consensus, justice, well-being, and civilization are the fundamental factors that create social conditions and the content of socialist democracy implementation in the social field in Vietnam during the transition to socialism. The great achievements of 35 years during the renovation process, including achievements in solving social problems and practicing socialist democracy in the social field, have confirmed that the policy of implementing solidarity, consensus, fairness, security, and civilization in the direction of socialism is suitable for the conditions of market economy development, building a socialist rule of law state and extensive international integration. These theoretical views are both the combination of the nation's fine tradition, the world's valuable experience, and the sustainable values of Marxism-Leninism and Ho Chi Minh thought as well as a reflection of the objective social needs of our country in the process of renovation and construction of socialism, and development of socialist democracy.

\subsection{Discussion}

Firstly, there is a contradiction between the requirement to ensure that the people truly master through the activities of the State, the whole political system, and other forms of direct democracy and representative democracy with the fact that the socialist rule-of-law state has just begun to build the mechanism for controlling power. Therefore, the social monitoring and detection role of the Vietnam Fatherland Front and its member organizations is still limited; The Party has not set an example in establishing socialist democracy [15].

Second, there is a contradiction between the requirement to ensure the socialist orientation, especially the Party's leadership, the management and development of the socialist rule-of-law State, and the people's right to economic mastery with the trend to strictly observe market laws in the building and developing a socialist-oriented market economy.

Third, the contradiction between the requirement to ensure the development of a society of solidarity, consensus, fairness, and civilization in the direction of socialism with manifestations of conflict of interests, social stratification, and many complicated social problems.

Fourthly, there is a contradiction between the requirement to ensure that culture is a solid spiritual foundation of society and an important endogenous force for sustainable development of the country and the fact that the cultural status of Vietnamese people still has many limitations and weaknesses.

\section{Conclusion}

From the 6th National Party Congress (1986) up to now, our Party's thinking, theoretical awareness on socialist democracy, and establishing socialist democracy have gradually been renewed and made significant strides. Along with the renovation and democratization of all areas of the country's social life, the Party's theoretical awareness of socialist democracy and socialist democracy establishment has been constantly supplemented and developed.

Accordingly, in the renovation process, from the practice of innovation and socialist democracy in the fields of the social life of the country in the past 35 years, our Party has initially formed a new system of theories on establishing socialist democracy in Vietnam. Therefore, in developing a socialist democracy in Vietnam during the renovation period, it is necessary to be steadfast on the theoretical foundation of 
Marxism - Leninism - a scientific theory and the revolution of the working class and the working masses. The scientific and radical revolutions of Marxism-Leninism and Ho Chi Minh Thought are sustainable values that have been pursued and implemented by revolutionaries. We need to absorb, selectively supplement in the spirit of criticism and creativity the latest achievements in thought and science, so our doctrines and theories are always fresh, not falling into stagnation, backwardness compared to life.

\section{References}

[1] Trong, N. P. (2021). On the road to socialism. Retrieved from: https://www.moha.gov.vn/tin-noi-bat/bai-viet-cua-tong-bi-thunguyen-phu-trong- ve-con-duong-di-len-cnxh-46173.html

[2] Communist Party of Vietnam (2010), Documents of the Party. Complete works. Vol, 49, p. 540. Hanoi: National Political Publishing House.

[3] Ly, P. T \& Thanh, N. T. Socialist rule-of-law State of Vietnam and issues facing publicity, transparency and accountability. Retrieved from: http://lapphap.vn/Pages/tintuc/tinchitiet.aspx?tintucid=210628

[4] Central Propaganda Department (2019). Reference material to update knowledge for officials and party members at grassroots level. Hanoi: National Politics Truth Publishing House.

[5] Party Central Council (2018). Textbook of scientific socialism. Hanoi: National Politics Truth Publishing House.

[6] Ho Chi Minh National Academy of Politics, (2018). Textbook of Senior political theory: Party building. Hanoi: Political Theory Publishing House.
[7] Thang, L. V \& Tuan, L. V (2018). Political thought People are the foundation" in Vietnamese history. Hanoi: National Politics Truth Publishing House.

[8] Party Central Committee (2015). Summary report on some theoretical and practical issues over 30 years of renovation (1986 - 2016). Hanoi: National Political Publishing House.

[9] Ho Chi Minh National Academy of Politics (2018). Textbook of senior political theory: History of the Communist Party of Vietnam. Hanoi: Political Theory Publishing House.

[10] Nham, T. (2004). Theoretical thinking with the cause of innovation. Hanoi: National Political Publishing House

[11] Communist Party of Vietnam, (2016). Document of the 12th National Party Congress. Hanoi: Office of the Party Central Committee, p. 169.

[12] Nghia, N. T. (2019). Anthology of philosophy. Hanoi: National Politics Truth Publishing House.

[13] Party Central Committee (1993). Resolution No. 05 NQ/HNTW of the Fifth Plenum of the Party Central Committee (Term VII) on continuing innovation and rural socio-economic development.

[14] Duc, P. V (Editor) (2013). Political orientation for the development of Vietnam and some solutions for implementation in the period 2011-2020. Hanoi: Social Sciences Publishing House.

[15] Communist Party of Vietnam, (2021). Document of the 13th National Party Congress of Deputies. Hanoi: National Political Publishing House. 